Beata Dobrowolska', Halina Mazurek ${ }^{2}$ Barbara Ślusarska', Danuta Zarzycka', Marianna Charzyńska-Gula ${ }^{3}$, Tomasz Cuber ${ }^{1}$

'Department of Nursing Development, Faculty of Nursing and Health Sciences, Medical University of Lublin

Head: Prof. I. Wrońska, RN, PhD

${ }^{2}$ Independent Public Health Care Centre in Pulawy

Head: J. Herda, MD, PhD

${ }^{3}$ Department of Oncology and Community Health Care, Faculty of Nursing and Health Sciences, Medical University of Lublin

Head: A. Stanisławek, MD, PhD

\title{
Health-promoting activities performed by nurses for patients with COPD
}

\author{
Działania pielęgniarskie z zakresu promocji zdrowia w grupie pacjentów chorych na POChP
}

The authors declare no financial disclosure

Abstract

Introduction: Chronic obstructive pulmonary disease (COPD) is the fourth most common cause of death in the world. The significance of health promotion is usually emphasised among the activities which nurses should undertake in relation to patients suffering from COPD.

The aim of the study was to analyse the frequency and types of health promotion activities undertaken by nurses in relation to patients suffering from COPD.

Material and methods: The diagnostic survey with the use of a questionnaire constructed by the authors was applied in the study. Data collected in 2008 among 132 nurses (100\%) working in outpatient and hospital healthcare sectors in Poland were quantitatively analysed.

Results: Nurses working in hospitals more frequently took part in diagnosing COPD (62.30\%) than those working in outpatient establishments did (33.40\%). Anti-smoking counselling was performed by $69 \%$ of respondents. Nurses very rarely used professional tools for the measurement of the level of nicotine addiction (6\%) or the level of motivation to fight the addiction (4\%). Activities in terms of health education carried out on a patient with COPD were declared by $66.67 \%$ of primary care nurses, and by $76.81 \%$ from hospitals. The nurses surveyed did not perform any monitoring of their recommendations and did not assess their effectiveness. Participation in interdisciplinary pulmonary rehabilitation programmes was declared by $9.53 \%$ of outpatient sector nurses and by $40.58 \%$ of nurses from hospitals.

Conclusions: Nurses' activities in relation to patients suffering from COPD have a mainly educational nature, but unfortunately they are casual, occasional and unplanned. Planned and formal inclusion of nurses in the process of realisation of health promotion programs for patients with COPD is recommended, i.e. by planning funds for the tasks which can be performed by them. More attention should be payed to professional training of nurses for realisation of the process of health education, especially anti-smoking intervention.

Key words: COPD, nurses, health promotion, health education, cigarette smoking

Pneumonol. Alergol. Pol. 2014; 82: 125-132

\section{Streszczenie}

Wstęp: Przewlekła obturacyjna choroba płuc (POChP) stanowi czwartą przyczynę zgonów na świecie. Wśród działań, które powinna podejmować pielęgniarka w stosunku do chorego na POChP, podkreśla się przede wszystkim znaczenie tych, które można określić jako promujące zdrowie.

Address for correspondence: Beata Dobrowolska, PhD, MPhil, MSN, RN, Medical University of Lublin, S. Staszica 4-6, 20-081 Lublin, tel.: +48 $814486888,+48797197715$. e-mail: bb.dobrowolska@gmail.com

DOI: 10.5603/PiAP.2014.0018

Praca wpłynęła do Redakcji: 15.07.2013 r.

Copyright (C) 2014 PTChP

ISSN 0867-7077 


\begin{abstract}
Celem pracy jest analiza częstości i charakteru podejmowanych przez pielęgniarki działań wchodzących w zakres promocji zdrowia wobec pacjentów z POChP.

Materiał i metody: Dokonano analizy ilościowej danych zebranych od 132 pielęgniarek (100\%) zatrudnionych w zamkniętej i otwartej opiece zdrowotnej województwa lubelskiego. Zastosowano metodę sondażu diagnostycznego, wykorzystując kwestionariusz ankiety własnego autorstwa. Materiał zgromadzono w 2008 roku.

Wyniki: Pielęgniarki pracujące w szpitalach znacznie częściej uczestniczyły w diagnozowaniu POChP (62,30\%) aniżeli pielęgniarki podstawowej opieki zdrowotnej (33,40\%). Poradnictwo antytytoniowe realizowało $69 \%$ respondentów. Badane pielęgniarki rzadko używają profesjonalnych narzędzi do pomiaru i oceny stopnia uzależnienia od nikotyny (6\%) oraz do pomiaru poziomu motywacji do walki z nałogiem (4\%). Prowadzenie edukacji zdrowotnej wobec chorych na POChP deklarowało 66,67\% pielęgniarek z P0Z i 76,81\% pielęgniarek zatrudnionych w szpitalach. Pielęgniarki nie prowadzą monitoringu udzielanych przez siebie porad oraz nie poddają ocenie ich skuteczności. 0 udziale w programach wielodyscyplinarnej rehabilitacji oddechowej mówiło tylko 9,53\% ankietowanych z POZ oraz $40,58 \%$ ankietowanych ze szpitali.

Wnioski: Prowadzone przez pielęgniarki działania w stosunku do chorego na POChP mają charakter głównie edukacyjny, niestety są jednak powierzchowne, okazjonalne i nie mają znamion zaplanowanego procesu. Zaleca się planowe, formalne włączenie pielęgniarek w realizację programów promocji zdrowia w grupie chorych na POChP poprzez zaplanowanie środków finansowych na realizowane przez nie zadania, jak również zwrócenie większej uwagi na przygotowanie pielęgniarek do realizacji procesu edukacji zdrowotnej, szczególnie poradnictwa antynikotynowego.
\end{abstract}

Słowa kluczowe: POChP, pielęgniarki, promocja zdrowia, edukacja zdrowotna, palenie papierosów

Pneumonol. Alergol. Pol. 2014; 82: 125-132

\section{Introduction}

The National Programme for the Early Diagnosing and Prophylactics of COPD in Poland [1], as part of the Global Initiative of Chronic Obstructive Pulmonary Disease [2], fulfils the aims of early diagnosis of COPD among smokers and the education of patients in accordance with the recommendations on minimal anti-smoking intervention [3, 4]. The implementation of this programme involves the medical workers, especially nursing personnel, from basic and specialist healthcare institutions.

Among the activities which nurses should undertake in relation to a patient suffering from COPD, the significance of health promotion is usually emphasised. They comprise, in particular, diagnostic and educational activities devoted to risk factor elimination, i.e. tobacco smoking habits, the patient's participation in complex breathing rehabilitation, and social support for the patient and his/her family [5, 6]. All these activities are pointed out as the latest recommendations by the Global Initiative for Chronic Obstructive Lung Disease GOLD [7].

COPD is a serious problem within the public health area. Halbert et al. [8], in their report, confirmed that $10 \%$ of people over 40 years of age suffer from COPD, as diagnosed in spirometric tests. In Poland respiratory tract diseases, with COPD as the most common, are fourth on the list of causes of death, and according to the prognosis the incidence and death rates due to COPD will increase $[9,10]$. Approximate data show that this disease occurs in $5 \%$ of women and $10 \%$ of men who are over 40 years of age. Each year in Poland approximately 14,000 people die of COPD [11].

COPD is a disease that develops over many years without any symptoms. The clinical symptoms reveal themselves in the late phase of the disease. This means that early diagnosis of COPD is difficult, and detecting advanced pathological lesions in the respiratory organs in the later period results in less effective therapy [12-14]. Contemporary procedures for COPD treatment do not decrease the intensity or stop the inflammation process that develops in bronchial airways or lung tissue. That is why there is a need to eliminate risk factors causing the disease, together with educating patients, which might cause them to quit smoking $[15,16]$. However, the spirometric test makes it possible to diagnose the disease in its early stage [12, 17]. Smoking addiction is the most important risk factor of COPD, and giving it up can inhibit the development of the disease [18, 19]. Regrettably, social perception of this fact is still insufficient. Activities undertaken in Poland for many years aimed at early diagnosis of COPD among the population of smokers might become the reason for greater awareness of the connection between cigarette addiction and the incidence of COPD among wider groups of society $[13,20,21]$.

Among the diagnostic activities that a nurse should undertake in relation to a patient suffering from COPD, the most common methods are environmental interview, assessment of the functioning of the patient's respiratory system and 
spirometry. These procedures are mainly used within the programmes of secondary prevention, aimed at detecting the disease at an early stage $[7,17]$. The contribution of educational activities is also very important in eliminating the risk factors of COPD, especially exposure to nicotine smoke [9, 22]. The main goal of these programmes is to decrease the incidence and disability caused by COPD. The education of patients suffering from COPD connected with pulmonary rehabilitation is treated as the basic and main element of preparing a patient for self-care and living with the disease [6, 22, 23].

Special significance is attributed to the anti-smoking intervention that should be performed by nurses. As research indicates, overcoming smoking addiction is one of the most effective and least expensive ways of reducing COPD symptoms, and prevention of the development of the disease. Nurses can play an essential role in that process $[24,25]$.

Research results show that the above-mentioned nursing activities towards patients suffering from COPD, undertaken with the cooperation of physicians, contribute to the improvement of patients' lives and reduce the mortality rate $[26,27]$. These results should not be neglected.

\section{Material and methods}

\section{The aim of the study}

The aim of the study was to analyse the frequency and types of health promotion activities undertaken by nurses in relation to patients suffering from COPD.

\section{Participants}

Participants were recruited from the outpatient and hospital healthcare sector of Lubelskie voivodeship. All registered nurses (having a diploma or baccalaureate degree) were qualified for participation in the study. Another criterion for participation in the study was work on pulmonary and internal disease wards - hospital nurses and GP practice or Community/Family nursing practice - as outpatient nurses.

Research assistants were trained in order to collect the data. They approached the nurses in the workplace and explained the purpose of the study. Those of the nurses who agreed to participate received the questionnaire with a cover letter that explained the aim of the study, and written consent was obtained. The questionnaires were completed anonymously, and there is no record of the nurses' personal details.
A total of 200 questionnaires were distributed among participants, of which 148 were returned completed. To the final analysis, 132 (100\%) questionnaires were classified as correctly and completely filled out.

\section{Data collection and analysis}

Quantitative analyses of data collected from 132 nurses $(100 \%)$ were made. The diagnostic survey with the use of self-constructed questionnaires formulated on the basis of a Polish and foreign literature review was applied in the study [2, 12, 17, 22, 23, 27].

The survey was preceded by a pilot survey (among 20 [100\%] nurses who worked in pulmonary and internal diseases hospital wards and were part-time nursing students at Masters level), which allowed verification of the research tool.

Data were collected in 2008 and analysed statistically with the use of the Chi-square Pearson test and Student's t-test assuming an error probability at the level of $P=0.05$.

The questionnaire consisted of 45 questions with 32 questions structured, 12 half open-ended and 1 open-ended. The tool also included questions to show the socio-demographical and professional characteristics of the respondents.

\section{The ethics of the survey}

All respondents were informed about the aim of the study, and, after giving consent to participation, they completed the questionnaires.

\section{Results}

\section{The characteristics of the surveyed group}

The specific characteristics of the respondents are included in Table 1.

\section{The diagnostic and educational activities of nurses in respect of patients suffering from COPD}

The data analysis shows that nurses working in hospitals more frequently take part in diagnosing COPD (62.30\%) than those who work in the outpatient healthcare sector do (33.40\%).

The working environment had a statistically significant influence on the respondents' answers concerning the participation of nurses in diagnosing COPD within educational and diagnostic programmes $(P<0.05)$. In this area the results are the opposite; nurses who work in the outpatient healthcare sector more frequently stated that they took part in these programmes (41.3\%) than the hospital nurses did (20.3\%). 


\section{Table 1. Socio-demographic profile of the surveyed} group

Tabela 1. Charakterystyka socjodemograficzna badanej grupy

\begin{tabular}{|c|c|c|c|}
\hline No. & Soc & io-demographic profile & $\%$ \\
\hline \multirow[t]{2}{*}{1} & \multirow[t]{2}{*}{ Gender } & Female & 100 \\
\hline & & Male & 0 \\
\hline 2 & \multicolumn{2}{|l|}{ Average of age } & 41.2 \\
\hline \multirow[t]{5}{*}{3} & \multirow{5}{*}{$\begin{array}{l}\text { Marital } \\
\text { status }\end{array}$} & Single & 15.15 \\
\hline & & Married & 73.48 \\
\hline & & Widowed & 2.27 \\
\hline & & Divorced & 3.03 \\
\hline & & Separated & 6.06 \\
\hline \multirow[t]{3}{*}{4} & \multirow[t]{3}{*}{$\begin{array}{l}\text { Place of } \\
\text { living }\end{array}$} & $\begin{array}{l}\text { City more than } 100,000 \\
\text { inhabitants }\end{array}$ & 37.1 \\
\hline & & $\begin{array}{l}\text { Town less than } 100,000 \\
\text { inhabitants }\end{array}$ & 43.9 \\
\hline & & Village & 18.9 \\
\hline \multirow[t]{4}{*}{5} & \multirow[t]{4}{*}{ Education } & Registered nurse & 67.4 \\
\hline & & Bachelor in nursing & 20.5 \\
\hline & & Master in nursing & 9.1 \\
\hline & & Master of other discipline & 3.0 \\
\hline \multirow[t]{4}{*}{6} & \multirow{4}{*}{$\begin{array}{l}\text { Postgraduate } \\
\text { education }\end{array}$} & Specialisation & 18.94 \\
\hline & & Qualification course & 26.52 \\
\hline & & $\begin{array}{l}\text { Qualification course in health } \\
\text { education and promotion }\end{array}$ & 3.79 \\
\hline & & $\begin{array}{l}\text { Training course in interpersonal } \\
\text { communications and health } \\
\text { education and promotion }\end{array}$ & 3.79 \\
\hline \multirow[t]{4}{*}{7} & \multirow[t]{4}{*}{ Employment } & Pulmunology ward & 34.1 \\
\hline & & Internal disease ward & 18.2 \\
\hline & & General practitioner practice & 33.3 \\
\hline & & $\begin{array}{l}\text { Community/family nursing } \\
\text { practice }\end{array}$ & 14.4 \\
\hline \multirow[t]{5}{*}{8} & \multirow{5}{*}{$\begin{array}{l}\text { Length of } \\
\text { employment }\end{array}$} & Less than 5 years & 9.1 \\
\hline & & $5-10$ years & 12.1 \\
\hline & & $10-15$ years & 13.7 \\
\hline & & $15-20$ years & 12.1 \\
\hline & & More than 20 years & 53.0 \\
\hline
\end{tabular}

Unfortunately, the nurses from both groups did not take part in the specific diagnostic process of COPD, e.g. the spirometric test: outpatient nurses $-49.21 \%$, hospital nurses - 60.87\%.

Anti-smoking counselling was performed by $69 \%$ of respondents, with no difference between hospital and outpatient environments. However, nurses very rarely used professional tools for the measurement and evaluation of the level of nicotine addiction:, e.g. Fagerström's Test: outpatient nurses - 9.62\%, hospital nurses $5.26 \%$. And for the measurement of the level of motivation to fight the addiction, outpatient nurses $-5.77 \%$, hospital nurses $-7.89 \%$. The most common educational materials used by nurses when they performed anti-smoking education, irrespective of working environment, were leaflets and brochures.

Encouraging results were achieved in the area of performing minimal anti-smoking intervention. The majority of respondents acknowledged performing such actions (outpatient nurses 69.84\%, hospital nurses - 81.16\%).

\section{Participation of nurses in the health education of a patients suffering from COPD}

Similar declarations were seen concerning the performance of health education towards patients suffering from COPD and their families. The majority of respondents, regardless of their work environment, confirmed this (outpatient nurses - 66.67\%, hospital nurses - 76.81\%). The most frequently mentioned issues in health education were issues related to disease $(68.12 \%$ of outpatient healthcare nurses, $68.25 \%$ of hospital nurses), lifestyle changes $(52.17 \%$ of outpatient healthcare nurses, $69.84 \%$ of hospital nurses) and anti-smoking intervention (59.42\% of outpatient nurses, $53.97 \%$ of hospital nurses).

The most widespread form of health education was the individual education of patients (78.95\% of outpatient nurses, $61.54 \%$ of hospital nurses). Considering the methods of education, the most frequently used was an individual conversation with a patient $(94.74 \%$ of outpatient nurses, $88.46 \%$ of hospital nurses). Less frequent were giving a talk $(55.26 \%$ of outpatient healthcare nurses, $21.15 \%$ of hospital nurses) and discussion $(26.32 \%$ of outpatient nurses, $30.77 \%$ of hospital nurses). Occasionally, nurses mentioned lectures, demonstrations with instructions, exercises or audiovisual methods.

The most common place used by hospital nurses to educate a patient was the patient's ward room (82.61\%), while outpatient nurses preferred the patient's home $(52.38 \%)$ or a room equipped with educational facilities (14.29\%).

Among people mentioned by respondents who nurses cooperate with most willingly when performing the process of health education were physicians (68.42\% of outpatient nurses, $48.08 \%$ of hospital nurses) and the patient's family ( $47.37 \%$ of outpatient nurses, $53.85 \%$ of hospital nurses). 
Table 2. Interests of patients with COPD in health education, in the opinion of nurses

Tabela 2. Opinie pielęgniarek na temat zainteresowania pacjentów z POChP edukacją zdrowotną

\begin{tabular}{|c|c|c|c|c|c|}
\hline \multirow[t]{2}{*}{ No. } & & \multicolumn{2}{|c|}{ Outpatient health care nurses } & \multicolumn{2}{|c|}{ Hospital nurses } \\
\hline & & n & $\%$ & $\mathbf{n}$ & $\%$ \\
\hline 1 & Definitely yes & 10 & 15.87 & 9 & 13.04 \\
\hline 2 & Rather yes & 42 & 66.67 & 43 & 62.32 \\
\hline 3 & Rather not & 11 & 17.46 & 15 & 21.74 \\
\hline 4 & Definitely not & 0 & 0.00 & 2 & 2.90 \\
\hline Overall & & 63 & 100.00 & 69 & 100.00 \\
\hline Chi-square Pearson test & \multicolumn{5}{|c|}{2.700} \\
\hline$P$ & \multicolumn{5}{|c|}{ NS } \\
\hline
\end{tabular}

Interesting results were obtained with regard to the issue of nursing diagnosis as the basis of health education. $36.51 \%$ of outpatient nurses and $44.93 \%$ of hospital nurses always preceded health education by formulating a nursing diagnosis. The tools used by respondents to assess the knowledge and skills of a patient in order to make a diagnosis was predominantly a questionnaire to be applied in an interview $(11.11 \%$ of outpatient nurses, $37.68 \%$ of hospital nurses). It is very alarming that the majority of respondents did not use any tools for the assessment of the level of knowledge and skills of a patient before the nursing diagnosis was made ( $66.67 \%$ of outpatient nurses, $39.13 \%$ of hospital nurses).

The results are also discouraging when looking closely at the nursing documentation of health education. Only $23.80 \%$ of outpatient healthcare nurses and $28.99 \%$ of hospital nurses confirmed the fact that they had any evidence of performing health education with a patient and his/her family. The more educated the respondents were, the more frequently they gave positive answers to the question concerning documentation of the health education process $(P<0.05)$.

The research attempted to verify the patients' interest in health education in the opinion of the nurses conducting it. The data are illustrated in Table 2.

In the opinion of the nurses, the effects of health education gave rise to some optimism. $74.60 \%$ of outpatient healthcare nurses and $82.60 \%$ of hospital nurses noticed an increased level of motivation for lifestyle change among educated patients. Hospital nurses (89.86\%) and outpatient nurses (79.36\%) observed attitude shaping and increasing self-care among patients with COPD under the influence of health education.
Regrettably, the assessment of the effectiveness of health education was generally based on a conversation with the patient and his/her family $-88.89 \%$ of outpatient nurses, $85.51 \%$ of hospital nurses. Among the rather infrequently mentioned methods were the monitoring of recommendations $(12.70 \%$ of outpatient nurses, $2.90 \%$ of hospital nurses) and using a prepared evaluation sheet $3.17 \%$ of outpatient healthcare nurses, $11.59 \%$ of hospital nurses).

\section{The participation of nurses in the interdisciplinary pulmonary rehabilitation process of patients suffering from COPD}

Nurses employed in hospitals more often participated in interdisciplinary pulmonary rehabilitation programmes adapted to the situation of each single patient suffering from COPD: outpatient nurses - 9.53\%, hospital nurses - 40.58\% (statistically significant correlation $P<0.05$ ).

The evaluation of the significance of the role of the nurse in the team implementing a programme of pulmonary rehabilitation by nurses showed that outpatient healthcare nurses gave 3.81 points on a six-grade scale, similarly to hospital nurses, who gave 3.96 points. According to the respondents, the role of the nurse in such a team mainly involved health promotion (outpatient nurses - 55.56\%, hospital nurses - 42.03\%) and health education (outpatient nurses - 39.68\%, hospital nurses - 57.97\%). The roles of the counsellor and the coordinator of the pulmonary rehabilitation programme were subsequently mentioned.

The self-evaluation of respondents concerning particular elements of pulmonary rehabilitation fared poorly. Outpatient healthcare nurses ranked this issue at 2.54 and hospital nurses at $3.33(P<0.02)$ on a six-grade scale. 


\section{Providing social support to patients suffering from COPD and their families}

Comparing the compiled results obtained from outpatient healthcare nurses and hospital nurses, it might be claimed that the latter group was more convinced about the wisdom of participating in preparing profiles of social support for patients with COPD and their families: $50.72 \%$ of hospital nurses gave the answer "definitely yes" in comparison to outpatient healthcare nurses $-38.10 \%(P<0.05)$.

A significant majority of respondents $(92.75 \%$ of hospital nurses, $90.47 \%$ of outpatient nurses) were convinced about the necessity of nurses' participation in measuring the demand for social support for patients with COPD and their families. Respondents most often provided informational support for patients (91.65\% of outpatient nurses and $86.96 \%$ of hospital nurses). Emotional support ranked lower $(30.16 \%$ of outpatient nurses and $37.69 \%$ of hospital nurses).

\section{Discussion}

The study illustrated that the majority of nurses did not perform spirometry during the care process of patients with COPD, and they also rarely took part in the implementation of pulmonary rehabilitation programmes.

The surveyed nurses confirmed the effectiveness of their educational activities. The majority of them observed an increased level of motivation for changing one's lifestyle and developing appropriate attitudes and skills for self-care among the educated patients. However, deeper analysis of the collected data shows that nurses' assessment has an intuitive nature without confirmation of preliminary and final evaluations of the educational process of patients. The methods used by nurses when educating patients were not diversified enough. They mainly used individual conversations with patients to educate them.

As Efraimsson et al. [9] maintain that the spirometric test performed by nurses has a positive influence on overcoming nicotine addiction. Apart from education about, and motivation of, patients to quit smoking, a vital element is to show them how smoking affects their respiratory capacity. Similar results were confirmed in the studies of CzajkowskaMalinowska et al. [20] and Górecka et al. [21].

Educational intervention is not sufficient when it is used only to increase the knowledge of patients. They need to implement knowledge into their personal lives and modify it [23]. The participation of a nurse in anti-smoking education is essential. The nurses who took part in the study declared their involvement in this process, but unfortunately the effectiveness of their activities is unknown. As other studies confirmed, nurses are generally not well prepared for anti-smoking counselling [24, 28, 29].

Carlson et al. [30] confirmed that patients prefer individual conversation as a method of education. Apart from this method, the effectiveness of the usage of videotapes and oral instruction was positively assessed by patients. It should be emphasised that the patient's age is a major factor in his/her education. Most COPD patients are elderly. Constantinidou and Baker's study about the styles of learning by elderly people illustrates that such patients effectively learn when some visual presentations are used [31].

There are studies which show the significance of the role of a nurse during the performance of health education. The results of Venning et al. [32] showed that patients were more satisfied with a counselling process led by a nurse than by a physician, which might result from the emotional support given by nurses. The current study confirmed that in the nurses' opinion, patients were more interested in health education performed by them. The results of the study by Majda [24, 29] concerning the preparation of nurses for minimal anti-smoking intervention [4] in accordance with the 4A's model (Ask, Advise, Assist, Arrange follow-up) showed that not a single person from the surveyed group had been prepared during training for such a kind of process. Similar results concern the professional group of physicians who, despite their awareness of the health risks of smoking, are not eager to help patients fight their addiction. The main reasons for not doing this, according to the doctors, were their sense of insufficient preparation for resolving patients' addiction problems, lack of time, scepticism about the effectiveness of anti-smoking therapy and the negative reactions of patients [33, 34]. The established odds for the success of minimal anti-smoking intervention is 1.69 (95\%; CI 1.45-1.98), which signifies a slightly higher effectiveness for this method than psychological or behavioural interventions (OR $=1.55$; $\mathrm{CI}$ 1.27-1.9) and is comparable with the effectiveness of nicotine replacement therapy $(\mathrm{OR}=1.71 ; 95 \%$; CI 1.60-1.83) [35]. Four per cent of smokers who participate in minimal anti-smoking intervention quit smoking for good [36].

Efraimsson et al. [9] showed that the educational background of patients with COPD positively influences their quality of life, their ability to stop smoking (6 out of 16 patients from the intervention group gave up smoking) and knowledge about the disease. Patients participating in health education noticed a reduction in respirato- 
ry distress symptoms, increased physical activity and improved psycho-social health.

Despite the fact that studies show that nurses and physicians have similar capabilities for the realisation of anti-smoking interventions and the results of their actions are similar, nurses are able to spend more time on the process of education and prevention. It is highlighted that physicians usually initiate counselling, while nurses continue this long process. [37] A meta-analysis of the research regarding nurses' anti-smoking interventions shows that nurses achieve very good outcomes in this regard when the process of education, counselling and support of the patient is well prepared and organised. Therefore, systematic work should be undertaken to ensure such nurses' activities are standard practice [38]. There are different solutions in Europe to ensure realisation of anti-smoking interventions by nurses. In many countries in Western Europe the use of Advanced Nurse Practitioners (ANPs) has been introduced. ANPs, after special training, play a vital role in working with patients addicted to nicotine, both in hospital and primary care settings [37]. Together with special training for medical staff carrying out anti-smoking interventions, in the UK, from 1990, additional payment has been introduced for the health promoting activity of GPs and practice nurses. The effects of this action are not recognised, but research shows that primary care staff held negative views about the pilot payments to promote smoking cessation, as well as previous health promotion payments. They rather suggest that additional payments made to practices for supporting smokers who are motivated to stop smoking or for setting up practice based smoking cessation clinics might be more acceptable [39].

The nurses surveyed rarely took part in the implementation of pulmonary rehabilitation programmes. This was also confirmed in the study conducted among Korean nurses. Their participation in pulmonary rehabilitation was limited to the completion of physicians' recommendations only. On the other hand, it has been proven that a nurse who performs rehabilitation, especially at the patient's home, effects his/her life by improving his/her respiratory capacity and increasing physical activity. In addition, rehabilitation should be connected with educating a patient, as the two are components of the same process. During breathing exercises led by the nurse, a patient might get information about symptoms, their interpretation, explanations how to use inhalation equipment, etc. [40].
Social support is also a crucial element in health promotion to patients suffering from COPD. In order to implement this action well, the fundamental and basic issue is to build a bond between the caregiver and the patient. Nurses most often gave informational support to patients, which shows the connection with educational activities. It must be emphasised that the individual emotional support given to COPD patients is meaningful. Combining it with other anti-smoking activities might increase the effects of health education [41].

\section{Limitations}

The conducted study concerned a limited group of nurses, who were employed in hospitals or the outpatient healthcare sector. Only 20\% of nurses from the surveyed group had accomplished specialisation in different disciplines of nursing, which surely influences their level of competence. It would be worth making a comparative analysis with a group of nurses who work only with patients with COPD. The results do not show how effective the anti-smoking intervention of nurses is, because the surveyed group did not assess their activities.

\section{Conclusions}

Nurses' activities in relation to patients suffering from COPD have a mainly educational nature, but unfortunately they are casual, occasional and unplanned. Nurses need to improve their competence in using professional educational programmes constructed for COPD patients. The education of patients must have a structure for the process, incorporating tools for measuring the demand for education and the motivation of patients for changing their lives, professional educational materials, and an assessment of the effectiveness of the performed educational activities.

\section{Postulates for clinical practice}

The increasing number of patients suffering from COPD influences the significance of health promotion activities undertaken by nurses. The clinical outcomes of COPD treatment and the quality of the lives of patients dealing with this disease can be improved through health promotion activities undertaken by nurses, but only when they are well prepared and carried out on a regular basis. There is a need to incorporate into nursing education and training programmes professional anti-smoking intervention and the development of skills for detecting nicotine addiction and the level of motivation of patients to 
change their health behaviour. It would also be useful to consider incorporation of solutions which have been checked in western countries, such as Advanced Nurse Practice and financial support of health promoting activities undertaken by GPs and nurses. Planned and formal inclusion of nurses in the process of realisation of health promotion programs for patients with COPD is recommended, i.e. by planning funds for the tasks (such as health education, counselling and support) that can be performed by them.

\section{Conflict of interest}

The authors declare no conflict of interest.

\section{References:}

1. Zieliński J., Roszkowski-Śliż K. Narodowy Program Wczesnego Rozpoznawania I Profilaktyki POChP. Pneumonol. Alergol. Pol. 2002; 70: 125-129.

2. Global initiative for chronic obstructive lung disease. Global strategy for the diagnosis, management and prevention of chronic obstructive pulmonary disease. NHLBI/WHO workshop report. National Institutes of Health. National Heart. Lung, and Blood Institute. Publ. No 2701, April 2001.

3. Grzywacz E. Minimalna interwencja antynikotynowa. Lekarz rodzinny a problem palenia papierosów. Lekarz Rodzinny 2000; 7-8: 96-97.

4. A clinical practice guideline for treating tobacco use and dependence (USA Public Health Service Report). JAMA 2000; 283: 3244-3248.

5. Bednarek M., Maciejewski J., Wozniak M., Kuca P., Zieliński J. Prevalence, severity and underdiagnosis of COPD in the primary care setting. Thorax 2008; 63: 402-407.

6. Damps-Konstańska I., Werachowska L., Krakowiak P. Rola opiekuna medycznego i wolontariusza w opiece nad chorymi na zaawansowaną postać przewlekłej obturacyjnej choroby płuc (POChP). Medycyna Paliatywna w Praktyce 2009; 3: 150-156.

7. Gold PhM. The 2007 GOLD guidelines: a comprehensive care framework. Respir. Care 2009; 54: 1040-1049.

8. Halbert R.J., Natoli J.L., Gano A., Badamgarav E., Buist A.S., Mannino D.M. Global burden of COPD: systematic review and metaanalysis. Eur. Respir. J. 2006; 28: 523-532.

9. Efraimsson E.Ö., Hillervik Ch., Ehrenberg A. Effects of COPD self-care management education at a nurse-led primary healthcare clinic. Scand. J. Caring Sci. 2008; 22: 178-185.

10. Wojtyniak B., Goryńsk P. (red.). Sytuacja zdrowotna ludności Polski. Narodowy Instytut Zdrowia Publicznego — Państwowy Zakład Higieny. Warszawa 2008.

11. Zalecenia Polskiego Towarzystwa Ftyzjopneumonologicznego rozpoznawania i leczenia POChP. Pneumonol. Alergol. Pol. 2004; 72, 1: 3-22.

12. Zieliński J. Wczesne wykrywanie POChP badaniem spirometrycznym grup wysokiego ryzyka. Pneumonol. Alergol. Pol. 2000; 68: 217-225.

13. Zielinski J., Bednarek M., Górecka D.G. et al. Increasing COPD awareness. Early detection of COPD by high risk — population screening. Eur. Respir. J. 2006; 27: 833-852.

14. Zieliński J. COPD - diagnosed too rarely, not only at an early-stage. Pneumonol. Alergol. Pol. 2007; 75: 2-4.

15. Roche N., Lepage T., Bourcereau J., Terrioux P. Guidelines versus clinical practice in the treatment of chronic obstructive pulmonary disease. Eur. Respir. J. 2002; 18: 243-247.

16. Global Initiative for Chronic Obstructive Pulmonary Disease (GOLD). Global strategy for the diagnosis, management and prevention of chronic obstructive pulmonary disease. Updated 2008, www.goldcopd.com.
17. Górecka D., Zieliński J. Early diagnosis and prevention of COPD in Poland; current status and perspectives. Pneumonol. Alergol. Pol. 2005; 73: 112-115.

18. Anthonisen N.R., Connett J.E., Murray R.P. Smoking and lung function of Lung Health Study participants after 11 years. Am. J. Respir. Crit. Care Med. 2002; 166: 680-685.

19. Hersh C.P., DeMeo D.L., Al-Ansari E. et al. Predictors of survival in severe, early onset COPD. Chest 2004; 126: 1443-1451.

20. Czajkowska-Malinowska M., Nowiński A., Górecka D., Zieliński J. Effects of spirometric screening in the community on smoking cessation. Pneumonol. Alergol. Pol. 2001; 69: 524-529.

21. Górecka D., Bednarek M., Nowiński A., Puścińska E., Goljan-Geremek A., Zieliński J. Diagnosis of airflow limitation combined with smoking cessation advice increases stop smoking rate. Chest 2003; 123: 1916-1923.

22. Biskupska K., Wysocki J. Program wczesnego wykrywania i zapobiegania przewlekłej obturacyjnej chorobie płuc (POChP). Menedżer Zdrowia 2003: 2: 69-71.

23. Bourbeau J., Nault D., Dang-Tan T. Self-management and behaviour modification in COPD. Patient Educ. Couns. 2004; 52: 271-277.

24. Majda A. Edukacja antynikotynowa i antyalkoholowa w praktyce pielęgniarek podstawowej opieki zdrowotnej. Zdrowie Publiczne 2003; 113: 237-243.

25. Lundh L., Rosenhall L., Törnkvist L. Care of patients with chronic obstructive pulmonary disease in primary healthcare. J. Adv. Nurs. 2006; 56: 237-246.

26. Vrijhoef H.J.M., Diederiks J.P.M., Spreeuwenberg C. Effects on quality of care for patients with NIDDM or COPD when the specialised nurse has a central role: a literature review. Patient Educ. Couns. 2000; 41: 243-250.

27. Bąk-Drabik K., Ziora D. Quality of life in chronic obstructive pulmonary disease. Pneumonol. Alergol. Pol. 2004; 72: 128-133.

28. Fetlińska J. Sprawozdanie z 12 Światowej Konferencji ‘Tobacco or Health'. Problemy Pielęgniarstwa 2003; 1-2: 109-113.

29. Majda A., Kulik T.B. Edukacja pielęgniarek podstawowej opieki zdrowotnej w zakresie profilaktyki uzależnień od nikotyny. Pielegniarstwo XXI wieku 2006; 4: 79-83.

30. Carlson M.L., Ivnik M.A., Dierkhising R.A., O’Byrne M.M., Vickers K.S. A learning needs assessment of patients with COPD. MEDSURG Nursing 2006; 15: 204-212.

31. Constantinidou F., Baker S. Stimulus modality and verbal learning performance in normal aging. Brain and Language 2002; 82: 296-311.

32. Venning P., Durie A., Roland M., Roberts C., Leese B. Randomized controlled trial comparing cost effectiveness of general practitioners and nurse practitioners in primary care. BMJ 2000; 320: 1048-1053.

33. Mierzecki A., Gąsiorowski J., Miączyńska M. Krótka interwencja antytytoniowa narzędziem dla lekarzy rodzinnych. Pneumonol. Alergol. Pol. 2002; 70: 216-219.

34. Suwała M., Więcławska I., Gerstenkorn A. The use of the minimal intervention strategy among police officers. Przegląd Lekarski 2008; 65: 647-650.

35. Lancaster T. Effectiveness of interventions to help people stop smoking: findings from the Cochrane Library. BMJ 2000; 321: 355-340.

36. Ashenden R., Silagry C., Weller D. A systematic review of the effectiveness of promoting lifestyle change in general practice. Family Practice 1997; 14: 160-165.

37. Noordman J. Lifestyle counseling by physicians and practice nurses in primary care. An analysis of daily care. NIVEL, Netherlands Institute for Health Services Research, Utrecht, The Netherlands, 2013.

38. Rice V.H., Stead L.F., Nursing intervention for smoking cessation. Cochrane Database of Systematic Reviews 2004; 1: CD001188.DOI:10.1002/14651858.CD001188.pub.2.

39. Coleman T., Wynn A.T., Stevenson K., Cheater F. Qualitative study of pilot payment aimed at increasing general practitioners' antismoking advice to smokers. BMJ 2001; 323: 432.

40. Kyung K., Chin P. The effect of a pulmonary rehabilitation programme on older patients with chronic pulmonary disease. J. Clin. Nurs. 2008; 17: 118-125.

41. Pbert L. Nurse-conducted smoking cessation in patient with COPD, using nicotine sublingual tablets and behavioral support. Chest 2006; 130: 314-316. 